\title{
Gestão na Educação Infantil: cenários do cotidiano, de Maria Aparecida Guedes Monção São Paulo: Loyola, 2021, 278 p.
}

\author{
iD Ligia de Carvalho Abões Vercelli \\ Doutora em Educação \\ Universidade Nove de Julho - Uninove. \\ São Paulo, SP - Brasil. \\ ligia@uni9.pro.br
}

\section{Para citar- (ABNT NBR 6023:2018)}

VERCELLI, Ligia de Carvalho Abões. Resenha. Eccos - Revista Cientifica, São Paulo, n. 59, p. 1-4, e20667, out./dez., 2021. Resenha. Gestão na Educação Infantil: cenários do cotidiano, de Maria Aparecida Guedes Monção São Paulo: Loyola, 2021, 278 p. https://doi.org/10.5585/eccos.n59.20667.

Maria Aparecida Guedes Monção é doutora em Educação, professora do curso de Pedagogia e do Programa de Pós-Graduação da Faculdade de Educação da Universidade Estadual de Campinas (Unicamp). Desenvolve pesquisas relacionadas aos temas políticas públicas em Educação Infantil, gestão escolar e formação de professores. Atuou como coordenadora do Fórum Municipal de Educação Infantil de São Paulo de 2012 a 2017 e atualmente é membro da diretoria do Centro de Estudos Educação e Sociedade (CEDES).

O livro Gestão na Educação Infantil: cenários do cotidiano é fruto de sua pesquisa de doutoramento, defendida no Programa de Pós-Graduação em Educação da Universidade de São Paulo (USP), no ano de 2013, sob orientação do Professor Doutor Vitor Henrique Paro, que prefacia a obra.

$\mathrm{Na}$ introdução do livro a autora aponta que são poucas as pesquisas na área da educação que discutem especificamente a gestão na Educação Infantil, destacando os trabalhos das seguintes autoras: Bianca Cristina Corrêa (2001, 2006), Mirian Tronolonne (2003), Eva Cristina Mendes (2007) e Cinthia Magda Fernandes Ariosi (2010). Diante dessa constatação, assinalamos a relevância acadêmica e social do livro ora resenhado.

Monção entende a Educação Infantil como espaço de socialização da criança pequena, direito delas e de suas famílias, o qual deve ser convertido em uma política pública. Busca, 
assim, compreender em que medida pode se efetivar uma gestão democrática que possibilite a relação cuidar/educar entre professores e familiares das crianças.

O objetivo geral é analisar a interação entre a família e o CEI, visando identificar a especificidade da administração educacional nesse segmento. A autora defende que o compartilhamento da educação da criança entre família e instituição tem de ser garantida pela gestão escolar.

A pesquisa baseou-se no aspecto qualitativo do tipo etnográfico, e os instrumentos de coleta de dados foram a observação participante e entrevistas semiabertas com roteiro préestabelecido com gestores, professores e familiares das crianças.

Além da introdução e das considerações finais, o livro está dividido em seis capítulos, a saber: O cenário da Educação Infantil no Brasil, no qual Monção discute os direitos fundamentais das crianças enquanto norteadores das políticas públicas e práticas cotidianas na Educação infantil; Gestão democrática na Educação Infantil, cuja análise está pautada na especificidade da gestão educacional e sua relação com a democracia e a singularidade da gestão na EI; Centro de Educação Infantil Anália Franco, no qual a autora apresenta a instituição em que foi realizada a pesquisa empírica, sua organização e o quadro de profissionais.

Além desses há os capítulos Cenas do cotidiano no CEI Anália Franco: em foco as relações entre adultos e crianças; Relações entre os adultos no CEI Anália Franco: tensões e contradições; Relação entre educadoras e famílias, em que Monção analisa os dados referentes às relações entre esses personagens. Vale lembrar que o nome da instituição é fictício.

Durante a leitura fui me impactando com os resultados apresentados, denunciados pela autora no decorrer da obra e em suas considerações finais. No que se refere à categoria relações entre adultos e crianças, Monção sinaliza a rotina da instituição: momentos de entrada e saída das crianças; troca de turnos das professoras; momentos de alimentação, higiene e descanso nos quais deve haver a integração entre cuidado e educação; “atividades" pedagógicas, e o papel das emoções.

O cuidado não é entendido como algo necessário à aprendizagem, mas um assistencialismo. Foram notadas práticas pedagógicas díspares no mesmo ambiente escolar por parte das professoras, umas atentas às crianças, outras nem tanto.

Verificam-se, de maneira geral, práticas autoritárias, com uso de contenção dos corpos, castigos e punições, formas de educar as crianças, sem muita atenção às demandas infantis, portanto amparadas em concepções tradicionais, que não mais se sustentam nesse segmento, revelando ações humanas pouco democráticas e afetuosas. Os profissionais da Educação 
Infantil precisam ter em mente que a criança necessita ser acolhida e respeitada para que se sinta segura e pertencente ao espaço escolar.

Nas relações interpessoais entre adultos, Monção verificou de que modo elas ocorrem entre gestoras e professoras e entre direção e coordenação e de que maneira essas ações reverberam nas famílias. A autora aponta o quanto a gestão fica impactada diante de certas atitudes dos professores em relação às crianças, impossibilitando um trabalho coletivo de qualidade. Nota-se a importância de discussões e reflexões em horários de formação para que as docentes possam avançar norteando suas práticas por teorias que as sustentem, abandonando o senso comum.

Uma gestão que se diz democrática pode deixar de incorporar às formações os Auxiliares Técnicos de Educação (ATE’s), que estão em constante contato com as crianças; nem mesmo os agentes escolares, os auxiliares de cozinha e limpeza e demais atores, conforme menciona Monção.

A participação das famílias na escola é contraditória, muitas aceitam de forma incondicional o que é proposto pelas profissionais, outras protestam, mas, de forma geral, não é dada a oportunidade, por parte das professoras, para que os pais expressem seus sentimentos. As reuniões de pais e professores é prescritiva, com informes repetitivos e não prioriza a voz dos responsáveis pelas crianças. Tal fato se deve à falta de participação dos pais na escola e de reflexões junto com eles a respeito do desenvolvimento infantil e do porquê de determinadas propostas pedagógicas.

Diante do exposto, Monção aponta que a visão assistencialista dos profissionais impede uma reflexão acerca da melhoria do trabalho coletivo, tais como: relatórios que depreciam as crianças, marcados por preconceitos em relação à população pobre; cotidiano improvisado, com muitas faltas de professores; reuniões pedagógicas sem articulação com discussões de momentos precedentes; predomínio de práticas de controle das crianças, como castigos e punições; pouca participação das famílias nos conselhos do CEI; dificuldade de comunicação entre professores e familiares.

As denúncias apresentadas por Maria Aparecida Guedes Monção, infelizmente, revelam uma escola da primeira infância que desrespeita os direitos fundamentais da criança. Segundo a autora, o conteúdo do livro 
não pode restringir-se a denúncia e indignação, com o risco de tornar-se mais um dos trabalhos que, ao descrever o "chão da escola", pode servir de munição para aqueles que não são comprometidos com a educação pública e denigrem sua imagem por meio da defesa do sistema de ensino privado, considerado símbolo de eficiência e sucesso, reforçando os interesses de mercado e a proliferação dos ideais neoliberais. Ao contrário, a proposta é que o conteúdo deste trabalho sirva como estímulo para defendermos com mais coragem a importância da educação pública infantil e da primeira infância, para garantir os direitos das crianças e de suas famílias (p. 264).

Os dados sinalizam o quanto os formadores de professores nos cursos de Pedagogia têm papel crucial ao apontar que as relações entre crianças e profissionais; professoras e gestoras; docentes e famílias devem estar pautadas na escuta, no diálogo e no respeito, principalmente em instituições que atendem crianças de 0 a 3 anos, demonstrada na pesquisa apresentada.

Trata-se de uma obra que merece ser lida por todos aqueles e aquelas que buscam atuar na Educação Infantil. A perspectiva crítica da autora causa sobressaltos, uma vez que ela apresenta uma realidade que (in)visibiliza a criança e suas famílias, além de apontar os graves problemas da educação brasileira.

Os resultados apresentados na presente obra convocam profissionais engajados, que cursaram e cursam pós-graduação lato e stricto sensu, a disseminar as pesquisas que apontam o "outro lado da moeda". Espera-se que tais profissionais ressignifiquem suas práticas e se coloquem sempre em busca de uma Educação Infantil pública de qualidade. Docentes e gestores, preocupados com as crianças, suas famílias e com a própria profissionalização também devem comprometer-se com a causa da primeira infância. 